\title{
EFFICIENCY OF NANOPOLYMER APPLICATION ON THE GROWTH, DEVELOPMENT AND YIELD OF SOYBEAN
}

\author{
Rashidova Dilbar Karimovna ${ }^{1}$, Amanturdiev Shavkat Balkibaevich ${ }^{2}$, Rashidova Sayora Sharafovna ${ }^{3}$ \\ ${ }^{1}$ Cotton Breeding, Seed Production and Agrotechnologies Research Institute, Tashkent, Uzbekistan \\ ${ }^{2}$ Tashkent State Agrarian University, Tashkent region, Uzbekistan \\ ${ }^{3}$ Institute of Chemistry and Physics of Polymers of the Academy of Sciences of the Republic of Uzbekistan, Tashkent, A.Kadiri str. 7b \\ Received - November 03, 2020; Revision - December 12, 2020; Accepted - December 24, 2020 \\ Available Online - December 30, 2020
}

DOI: http://dx.doi.org/10.18006/2020.8(6).799.809

\section{KEYWORDS \\ Soybean \\ Nanopolymer preparations \\ Enzyme content \\ Micronutrient \\ Growth}

Productivity

\begin{abstract}
The current study was carried out to analyze the effects of agro-nanopolymer preparations application on the seed germination, seedling and root sprout lengths, growth, development, yield, and resistance to Fusarium wilt in Baraka and Selecta-302 soybean variety under laboratory condition. For encapsulation of soybean seeds and nanopreparation UZHITAN, nanochitosan, chitosan (initial), polymer metallocomplexes (PMCs) of copper and silver ions were used at various ratios for nanoascorbate chitosan, ascorbate chitosan, polymer metallocomplex (PMC) $\mathrm{Cu}^{2+}: \mathrm{Ag} 7: 3$ and $\mathrm{PMC} \mathrm{Cu}^{2+}: \mathrm{Ag} \mathrm{8:2}$ preparations,. Results of the study revealed a significant effect of these agronanoplymers on the studied soybean varieties; application of this nanoascorbate chitosan, ascorbate chitosan, polymer metallocomplex (PMC) $\mathrm{Cu}^{2+}: \mathrm{Ag}$ 7:3 and PMC $\mathrm{Cu}^{2+}: \mathrm{Ag} \mathrm{8:2}$ showed $17 \mathrm{~g}, 14.6 \mathrm{~g}, 13.5 \mathrm{~g}$, and $11.9 \mathrm{~g}$ weight of the 1000 -grains respectively which was significantly higher than the Gaucho treatment. Further, these agronanoplymers also have a significant effect on the various yield attributes such as number of beans per plant, number of seeds per bean, and seed mass per bean. Application of chitosan and PMC agronanopolemers increased productivity by 4.5-6.1 $\mathrm{kg} / \mathrm{ha}$ and 3.3-5.1 kg/ha, respectively, compared to the control. Also, the effect of these agro nanopolymer preparations on enzyme activity and protein content was studied in the current study. Among the various tested nanopreparation, the greatest effect on total soybean yield was observed when seeds were treated with nano ascorbate chitosan. All nanopreparation treated seeds has a significant effect on the accumulation of macro and micronutrient accumulation in Soybean seed and except few one rest are the superior to the control and UZHITAN.
\end{abstract}

* Corresponding author

E-mail: etoile111@yandex.ru (Rashidova Dilbar Karimovna)

Peer review under responsibility of Journal of Experimental Biology and Agricultural Sciences.

Production and Hosting by Horizon Publisher India [HPI] (http://www.horizonpublisherindia.in/).

All rights reserved.
All the articles published by Journal of Experimental Biology and Agricultural Sciences are licensed under a Creative Commons Attribution-NonCommercial 4.0 International License Based on a work at www.jebas.org.

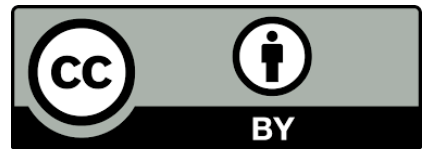




\section{Introduction}

In recent decades, the introduction of nanotechnology for agricultural applications has been widespread throughout the world. Over the past 10 years, the worldwide production of chitosan has reached more than 3,000 tons and the USA, Japan, India, China, Italy, and Russia are the leaders of chitosan production. More than $15 \%$ of the chitosan is globally produced by Primex while approximately $25 \%$ of the chitosan is produced and sold by Japanese firms.

Worldwide, researchers from various countries such as the USA, Japan, India, China, Vietnam, Germany, Russia, and Uzbekistan are researching to study the effect of nano polymer preparations on the seed sowing quality, growth, development, and yield of crops. Research is being conducted to study the effects of nanomaterials on seeds and plants and the resulting products affecting metabolic processes in plants.

Albumin-rich soy is a worldwide one of the main industrial crops Various biotic and abiotic factors including pathogenic microbe's affect soybean seed's survival and germination. To overcome such adverse situations, soybean seeds are usually treated with various preparations before sowing (Ge et al., 2013; Chau et al., 2019; Coman et al., 2019).

Nanotechnology can play a vital role in increasing agricultural production. The properties of nanoparticles not only depend on their physical nature, production method, size, and structure but also depend on the biological model on which the tests are carried out (Tikhonov et al., 2000; Fedorenko et al., 2006; Cheng et al., 2016; Cheng et al., 2017; Sendra et al., 2017).

Nanotechnology products, such as engineering nanomaterials (ENM), are among the new and exciting discoveries of the current century. These ENMs are with sizes that ensure biological interactions, have contributed to many revolutionary developments, from energy production and storage to agriculture and environmental management to targeted delivery systems (Tong et al., 2007; Johansen et al., 2008; Ghormade et al., 2011; Nowack et al., 2012; Priester et al., 2013; Ge et al., 2013). It has been established that plants can use the surface energy of these nanoparticles. Further, pre-sowing treatment of seeds with nanoparticles has a prolonged effect on seedling growth and cellular level development (Астафурова et al., 2011; Didenko et al., 2005; Hernandez-Viezcas et al., 2013).

Chitosan is a multifunctional polymer, which is derived from chitin, and it is known for its unique microbial degradability, biocompatibility and nontoxicity (Zeng \& Zhang, 2010). Chitin, chitosan and their derivatives, which have several valuable physicochemical and biomedical properties, have been the subject of numerous studies form last 200 years. The solubility of chitosan and its derivatives in aqueous media opened up new possibilities for creating unique polymer systems that can be used in the field of agriculture (Tikhonov et al., 2000). Further, Chitosan also possessed fungicidal (Kulikov et al., 2006a), virucidal (Kulikov et al., 2006b; Stevanoic et al., 2012), bactericidal (Chirkov, 2002; Gerasimenko et al., 2004; Didenko et al., 2005; Rashidova \& Milusheva, 2009) and immunomodulatory (Pomogaylo et al., 2000; Zorin, 2004) properties. This material also has anti-radiation effects (Ilyin et al., 2004; Varlamov et al., 2005) and are used as sorbents (Aktuganov et al., 2003), and flocculants (Bykova et al., 2004) in the creation of nematode-resistant preparations (Vasyukova et al., 2001; Kandrashina, 2006) and growth regulators (Rashidova \& Milusheva, 2009).

In the Republic of Uzbekistan, for the first time, the role of polymers in the creation and use of polymer preparative forms of chemical plant protection products was identified by Rashidova et al. (2013) and Rashidova et al. (2008). In Uzbekistan, waste from the natural silk production in the form of silkworm pupae is a source of chitin and chitosan (Rashidova \& Milusheva, 2009). The use of polymers for crops seed encapsulating has been scientifically substantiated by targeted selection and polymer synthesis (Milusheva et al., 2002; Rashidova et al., 2005; Rashidova et al., 2006; Rashidova \& Milusheva 2009; RUz patent No. IAP 03956, 2009). Based on the "Method for encapsulating seeds" (No. IAP03956) and "Composition for pre-sowing treatment of seeds of crops and method for its preparation" (No. IAP 2013 0271), the Intellectual Property Agency of the Republic of Uzbekistan issued two patents (IAP 03956, 2009). UZHITAN is a mixture of chitosan and CMC polymers and has water-soluble properties (Rashidova \& Voropaeva, 2006). Chitosan with a certain degree of deacetylation is used as part of the polymer UZHITAN preparation (a disinfectant with a stimulatory effect), which is registered with the State Chemical Commission of the Republic of Uzbekistan for use in the agricultural sector (Fedorenko et al., 2006).

Zeng \& Zhang (2010) used a new preparation 55-F-1 to encapsulate soybean variety seeds, which includes carboxymethylchitosan as the main component, microelements as a supplement, and growth regulators to stimulate the germination and growth. Results of this study revealed that the yield of 55-F-1 treated soybean seeds increased by $17.95 \%$. Further, this preparation also has a significant effect on the antifeedant effect activities and provides fundamental protection to the crops from pest damage.

Similarly, various researchers reported a highly significant stimulatory effect of nanoformulation application on the germination and growth of soybean seedlings. Further, among these Co- and Mo-containing nanoscales formulations led to the 
highest growth indices (excess of approximately 10\%). Enzymatic analysis of shoots from nano-processed soybean plants also revealed a similar result (Chau et al., 2019).

Positive effects of engineering nanomaterials on germination and growth of soybeans were recorded when low concentrations of $\mathrm{ZnO}(50 \mathrm{mg} / \mathrm{kg}$ ) and iron oxides were applied to the soil (both to the soil and through topdressing). Further, $\mathrm{TiO}_{2}$ had an almost neutral effect, while $\mathrm{CuO}$ and $\mathrm{Cr}_{2} \mathrm{O}_{3}$ negatively affected the soybean plant development (Coman et al., 2019). Further, at higher concentration of $\mathrm{ZnO}$ nanoparticles $(500 \mathrm{mg} / \mathrm{L}-2000 \mathrm{mg} / \mathrm{L})$ have an inhibitory effect on the root growth of soybean root (Lin \& Xing, 2007; López-Moreno et al., 2010; Yoon et al., 2014; Tamuly et al., 2014).

To obtain high and guaranteed soybean crops, the use of promising technologies for the preparation of sowing seeds, which involves the use of a wide range of environmentally friendly plant protection products, is important. The current study was aimed to evaluate or study the effect of nano preparation application on germination, seedling growth, root lengths, yield development, enzymatic activities, protein content, micro and macronutrient concentration, and Fusarium wilt resistance in the Baraka and Selecta-302 varieties of soybean under laboratory conditions. Additionally, the behavior of the nano preparation when interacting with biological materials during the metabolic processes of plants was also examined.

\section{Materials and methods}

In the current study seeds of two soybean varieties viz., Baraka and Selecta-302 were used, these two are included in the State Register of Agricultural Crops and recommended for sowing in the Republic of Uzbekistan. Before the showing, these seeds were encapsulated/treated with various active nanoagropolymer preparations such as UZHITAN, nanochitosan, polymer metallocomplexes of copper and silver ions at various ratios. Further, nanoascorbate chitosan and ascorbate chitosan based on chitosan and its derivatives are synthesized in the Laboratory of Advanced Polymers Synthesis, Institute of Chemistry and Physics, Republic of Uzbekistan. As a standard reference treatment, soybean seeds were dressings with Gaucho/Dalbron/Uzgumi, which are approved agro-industrial complex by the State Chemical Commission of the Republic of Uzbekistan for use agriculture while untreated seeds were used as a control.

The germination of soybean seeds was determined according to GOST 12038-86 "germination determination methods for crops seeds." Under laboratory conditions, micro-and macronutrients concentrations were determined $(\mathrm{mg} / \mathrm{kg})$ in seeds and one-monthold soybean plants as well as during the flowering and ripening stage by using an ECO and Optima 240 ODV US ICP instrument. For the estimation of fusariosis incidence on the soybean leaves and roots, the method of Syrmolot (2015) was used. The obtained results were analyzed using the SPSS program.

\section{Results and Discussion}

Influence of various nanopolymer preparations i.e. $\mathrm{PMC} \mathrm{Cu}^{2+}: \mathrm{Ag}$ 7:3, PMC $\mathrm{Cu}^{2+}: \mathrm{Ag} \quad 8: 2 \quad(0.5 \%)$; chitosan ref. (0.5\%), nanochitosan $(90 \mathrm{kDa})$, ascorbate chitosan, nanoascorbate chitosan @ $0.5 \%$ (4:1), and UZHITAN on the germination of soybean seeds was studied in the laboratory of Biochemistry and Plant Physiology at the Cotton Breeding, Seed Production and Agrotechnologies Research Institute, Tashkent, Uzbekistan. Seeds treated with Dalbron were used as a reference, and untreated seeds were used as a control. The laboratory germination of Baraka soybean seeds was studied on 3 and 7 days of inoculation (Table 1). Among the various tested nano preparations, maximum seed germination was reported with the

Table 1 Effect of various nanopreparation applications on the germination of soybean variety Baraka seeds in 2019

\begin{tabular}{|c|c|c|c|c|c|c|c|}
\hline \multirow{3}{*}{ № } & \multirow{3}{*}{ Treatment } & \multicolumn{6}{|c|}{ Germination (\%) } \\
\hline & & \multicolumn{3}{|c|}{ Oksuv Farm } & \multicolumn{3}{|c|}{ Moygir Yusufkhon Farm } \\
\hline & & After 3 days & On 7th day & $\begin{array}{l}+ \text { relative to } \\
\text { the control }\end{array}$ & After 3 days & On 7 th day & $\begin{array}{l}+ \text { relative to } \\
\text { the control }\end{array}$ \\
\hline 1 & Control & $81.0 \pm 0.6$ & $85.2 \pm 0.5$ & 0 & $81.4 \pm 0.4$ & $86.2 \pm 0.4$ & 0 \\
\hline 2 & Dalbron (standard) & $82.7 \pm 0.7$ & $86.3 \pm 0.4$ & +1.1 & $80.0 \pm 0.3$ & $86.5 \pm 0.5$ & +0.3 \\
\hline 3 & UZHITAN (standard) & $83.5 \pm 0.4$ & $88.0 \pm 0.6$ & +3.2 & $80.5 \pm 0.2$ & $88.0 \pm 0.6$ & +1.8 \\
\hline 4 & $\mathrm{PMC} \mathrm{Cu}^{2+}: \mathrm{Ag} \mathrm{7:3}$ & $85.2 \pm 0.3$ & $89.0 \pm 0.6$ & +3.8 & $83.2 \pm 0.5$ & $84.5 \pm 0.4$ & -1.7 \\
\hline 5 & $\mathrm{PMC} \mathrm{Cu}^{2+}: \mathrm{Ag} 8: 2$ & $83.0 \pm 0.2$ & $87.2 \pm 0.3$ & +2.0 & $80.7 \pm 0.5$ & $86.7 \pm 0.2$ & +0.5 \\
\hline 6 & Chitosan source $(0.5 \%)$ & $84.7 \pm 0.5$ & $90.2 \pm 0.4$ & +5.0 & $86.4 \pm 0.4$ & $88.2 \pm 0.4$ & +2.0 \\
\hline 7 & Nanochitosan $(0.5 \%)$ & $86.0 \pm 0.4$ & $92.5 \pm 0.2$ & +5.3 & $84.7 \pm 0.6$ & $90.5 \pm 0.5$ & +4.3 \\
\hline 8 & Ascorbate chitosan & $85.6+0.5$ & $90.4 \pm 0.4$ & +5.2 & $86.5+0.6$ & $91.2+0.4$ & +4.7 \\
\hline \multirow[t]{2}{*}{9} & Nanoascorbate chitosan & $88.6 \pm 0.4$ & $92.5 \pm 0.5$ & +7.3 & $82.0 \pm 0.4$ & $92.0 \pm 0.3$ & +5.8 \\
\hline & & $\mathrm{NSR}_{05}=2.23 \%$ & & & $\mathrm{NSR}_{05}=2.88$ & & \\
\hline
\end{tabular}

Journal of Experimental Biology and Agricultural Sciences http://www.jebas.org 
nanochitosan @ 0.5\% (90 kDa) and nanoascorbate chitosan @ $0.5 \%$ (4:1), with a germination rate of $92.5 \%$ and $90.5 \%$, respectively, and these two are $4.3-7.3 \%$ exceeding than the control and 3.2-6.2\% than the standard agrochemicals Dalbron.

Results of the study revealed that encapsulation of soybean seeds with nanoascorbate chitosan @ 0.5\% (4:1) and nanochitosan @ $0.5 \%(90 \mathrm{kDa})$ positively affect the laboratory germination of soybean seeds and can be recommended to the farmers for better soybean production.

Effect of nanopreparation on the seedling growth of Baraka soybean seeds obtained from Oksuv Farm of Kurgantepa and Maygir Yusufkhon Farm of the Izboskan district of Andijan region was studied. Seeds obtained from these two farms were encapsulated by the above-said nanopreparation and sown in phytotron vessels and the length of the seedlings and roots were measured after 10 days of germinations. The aboveground and below-ground parts of the seedlings treated with nano preparation were longer than those in the control by $0.9 \mathrm{~mm}$ to $4.4 \mathrm{~mm}$. Results are in agreement with the findings of Shah et al. (2016).

Among the various tested combinations, best seedling and root growth was reported in the seeds encapsulated with nanoascorbate chitosan@ 0.5\% (4:1). Specifically, this treatment has $10.9-11 \%$ longer seedlings than the control. A similar result was obtained for the below-ground part (Table 2). Further, the results of study revealed that various other nano preparations i.e. nanoascorbate

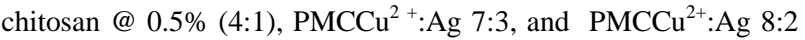
also have high significant biological activities and increases the length of the above and below ground parts of tested seedlings. Plants from seeds treated with UZHITAN were taller than those in the control.

Under laboratory conditions, the concentrations of macro - and microelements $(\mathrm{mg} / \mathrm{kg})$ were determined in seeds and one-monthold soybean plants (Tables 3). Results of the study revealed that the concentrations of micro-and macroelements in the soybean seeds are higher than the one-month-old plants except for calcium and Sodium. Among the tested element, copper was reported in the

Table 2 Effect of nano preparation application of the seedling and root growth of Baraka soybean seedlings

\begin{tabular}{|c|c|c|c|c|c|c|c|c|c|c|c|c|c|}
\hline \multirow[b]{2}{*}{ № } & \multicolumn{7}{|c|}{ Oksuv Farm } & \multicolumn{6}{|c|}{ Moygir Yusufkhon Farm } \\
\hline & Options & $\begin{array}{l}\text { Aboveground } \\
\text { part }(\mathrm{mm})\end{array}$ & $\mathrm{C}$ & V & $\begin{array}{l}\text { Belowground } \\
\text { part (mm) }\end{array}$ & $\mathrm{C}$ & $\mathrm{V}$ & $\begin{array}{l}\text { Aboveground } \\
\text { part (mm) }\end{array}$ & $\mathrm{C}$ & V & $\begin{array}{l}\text { Belowground } \\
\text { part }(\mathrm{mm})\end{array}$ & $\mathrm{C}$ & $\mathrm{V}$ \\
\hline & Control & $34.8+0.4$ & 1.14 & 3.2 & $86.6+0.4$ & 1.2 & 1.4 & $35.3+0.3$ & 0.9 & 2.6 & $88.4+0.4$ & 1.3 & 3.0 \\
\hline & Dalbron (standard) & $35.6+0.5$ & 1.4 & 4.0 & $89.7+0.4$ & 1.1 & 1.3 & $35.8+0.3$ & 1.0 & 2.9 & $89.6+0.5$ & 1.7 & 1.9 \\
\hline & UZHITAN (standard) & $36.0+0.3$ & 1.0 & 2.7 & $89.6+0.3$ & 1.0 & 1.2 & $35.9+0.3$ & 1.0 & 2.8 & $89.7+0.3$ & 1.1 & 2.8 \\
\hline & $\mathrm{PMC} \mathrm{Cu}^{2+}: \mathrm{Ag} \mathrm{7:3}$ & $38.0+0.4$ & 1.4 & 3.7 & $97.2+0.3$ & 0.9 & 0.9 & $37.8+0.4$ & 1.5 & 3.8 & $94.8+0.4$ & 1.3 & 3.4 \\
\hline & $\mathrm{PMC} \mathrm{Cu}^{2+}: \mathrm{Ag} 8: 2$ & $37.6+0.2$ & 0.9 & 2.4 & $96.5+0.4$ & 1.1 & 1.2 & $39.2+0.6$ & 2.1 & 5.3 & $99.1+0.5$ & 1.6 & 4.5 \\
\hline & Chitosan source $(0.5 \%)$ & $35.3+0.3$ & 1.15 & 3.3 & $89.7+0.3$ & 1.1 & 1.2 & $36.8+0.5$ & 1.5 & 4.3 & $92.4+0.3$ & 1.1 & 1.2 \\
\hline & $\begin{array}{l}\text { Nanoascorbate chitosan } \\
(0.5 \%)\end{array}$ & $38.6+0.4$ & 1.1 & 2.9 & $97.4+0.4$ & 1.4 & 1.4 & $39.7+0.4$ & 1.2 & 2.9 & $99.4+0.5$ & 1.4 & 4.2 \\
\hline & Nanochitosan $(0.5 \%)$ & $37.9+0.3$ & 0.8 & 2.3 & $91.7+0.3$ & 1.0 & 1.2 & $37.9+0.3$ & 1.1 & 2.9 & $96.6+0.4$ & 1.2 & 2.9 \\
\hline
\end{tabular}

Table 3 Effect of various nano preparation applications on the contents of micro-and macroelements in Baraka soybean seeds and plants

\begin{tabular}{|c|c|c|c|c|c|c|c|c|c|c|c|}
\hline \multirow{3}{*}{ № } & \multirow{3}{*}{ Preparation } & \multicolumn{10}{|c|}{ Micro \& Macroelements $(\mathrm{Mg} / \mathrm{Kg})$} \\
\hline & & \multirow{2}{*}{$\begin{array}{l}\text { Copper } \\
\text { Seed }\end{array}$} & \multirow[b]{2}{*}{ Plant } & \multirow{2}{*}{$\begin{array}{l}\text { Iron } \\
\text { Seed }\end{array}$} & \multirow[b]{2}{*}{ Plant } & \multicolumn{2}{|c|}{ Potassium } & \multicolumn{2}{|l|}{ Calcium } & \multicolumn{2}{|l|}{ Sodium } \\
\hline & & & & & & Seed & Plant & Seed & Plant & Seed & Plant \\
\hline 1. & Control & 11.91 & 4.24 & 113.92 & 31.12 & 11942.4 & 5856.17 & 2524.85 & 6187.38 & 306.47 & 652.16 \\
\hline 2. & UZHITAN (Standard) & 11.12 & 4.24 & 91.88 & 24.71 & 11026.5 & 4271.15 & 2241.25 & 5879.3 & 201.54 & 691.22 \\
\hline 3. & Ascorbate chitosan & 16.90 & 7.05 & 126.06 & 25.43 & 11992.7 & 6869.73 & 2687.25 & 5589.71 & 303.52 & 526.24 \\
\hline 4. & Nanoascorbate chitosan $(0.5 \%)$ & 12.04 & 7.16 & 93.43 & 31.22 & 12841.2 & 5289.41 & 2684.82 & 5427.32 & 262.85 & 557.40 \\
\hline 5. & Chitosan source $(0.5 \%)$ & 11.92 & 5.13 & 92.33 & 22.33 & 12940.8 & 6068.19 & 2727.61 & 6068.49 & 260.13 & 489.49 \\
\hline 6. & Nanochitosan $(0.5 \%)$ & 11.33 & 6.13 & 91.28 & 26.38 & 13823.8 & 4227.42 & 2281.38 & 4237.58 & 292.63 & 519.43 \\
\hline 7. & $\mathrm{PMC} \mathrm{Cu}^{2+}: \mathrm{Ag} 7: 3$ & 13.99 & 5.19 & 116.43 & 30.10 & 10231.5 & 5242.13 & 2276.41 & 5465.84 & 275.82 & 608.57 \\
\hline 8. & $\mathrm{PMC} \mathrm{Cu}^{2+}: \mathrm{Ag} 8: 2$ & 15.96 & 5.04 & 118.22 & 32.77 & 11470.7 & 6085.49 & 2513.28 & 5923.24 & 268.48 & 591.46 \\
\hline
\end{tabular}

Journal of Experimental Biology and Agricultural Sciences

http://www.jebas.org 
lowest concentration while potassium was available in the highes concentration. In seeds treated with nano preparation, the concentration of micro and macroelements are higher than the onemonth-old plants (Table 3).

The concentration of copper and iron in soybean seeds treated with ascorbate chitosan was 16.90 and $126.032 \mathrm{mg} / \mathrm{kg}$ respectively while this concentration was 7.05 and $25.43 \mathrm{mg} / \mathrm{kg}$ for the onemonth-old plants respectively. Compared to the control and UZHITAN the concentration of copper, iron, potassium, calcium,

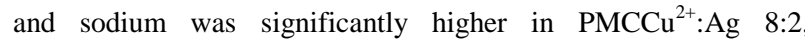
$\mathrm{PMCCu}^{2+}: \mathrm{Ag}$ 7:3 and ascorbate chitosan was higher.

The contents of the macronutrients potassium and calcium are significantly higher in Ascorbate chitosan, Chitosan source (0.5\%), and Nanochitosan $(0.5 \%)$ treated seeds and one-month-old soybean plants. This shows that plants in the initial period require an increase in these macronutrients for development.

Seeds and plants of the soybean variety Selecta-302 were obtained from Durdona Farm, Pakhtakor district of the Jizzakh region and the contents of micro-and macroelements were determined during the flowering and fruiting periods (Table 4).

All seeds except those are treated with nanochitosan $(24.80 \mathrm{mg} / \mathrm{kg})$ showed a lower copper content than the control $(16.46 \mathrm{mg} / \mathrm{kg})$. Among the various tested combinations, the lowest copper content was reported in ascorbate chitosan $(4.17 \mathrm{mg} / \mathrm{kg})$ which was 12.29 $\mathrm{mg} / \mathrm{kg}$ lower than control (Table 4 ). In the case of plants, all nano preparation treatments have a lower value than the controls. In the case of standard treatments UZHITAN and Uzgumi, these two have lower concentrations of all micro and macroelements as compared to the control. Further, the amount of seed iron and potassium was also reported lower than the control while in the case of calcium and Sodium concentration, all treatments except Chitosan source (31241.52 \& 673.37 respectively) and PMC $\mathrm{Cu} 2+: \mathrm{Ag}$ 7:3 (30260.15 \& 949.69 respectively) have a lower concentration than the control (Table 4).

An increase in iron during the fruiting period was observed under treatment ascorbate chitosan, nanoascorbate chitosan, and PMC $\mathrm{Cu}^{2+}: \mathrm{Ag} \mathrm{8:2}$ while in the rest treatments iron content decreased as compared to that in seeds. The results of potassium concentration at the fruiting period also showed the highest concentration of potassium ion in seed treated with ascorbate chitosan and this is significantly different from the control. Compared to the seeds, the potassium content in fruiting plants grown from seeds treated with $\mathrm{PMC} \mathrm{Cu}^{2+}: \mathrm{Ag} \mathrm{7:3} \mathrm{treatment} \mathrm{increased} \mathrm{by} 15.4 \%$. Determination of the calcium content showed that the seeds treated with the ascorbate chitosan and UZHITAN preparations had 11.2 and 7.1 times lower calcium content than the control plants, respectively. The calcium content during the fruiting period has been decreased as compared to the seeds treated with nanoascorbate chitosan, chitosan, nanochitosan, PMC Cu2+:Ag 7:3, and PMC Cu2+:Ag $8: 2$. The data obtained from the study revealed that the use of nano preparations for the treatment of soybean seeds significantly affects the contents of micro-and macroelements.

The results of the micro and macro elements concentration at flowering and fruiting stage in various nano preparations treated plants are presented in table 5. Except for Chitosan source and Nanochitosan, all other nano preparations have lower copper concentrations as compared to the standard treatment. For other preparations, a decrease in the concentration of copper during the period of fruit formation was observed (Table 5). In terms of iron

Table 4 Effect of various nano preparations on the micro-and macroelements in the seeds and plants at the fruit formation stage of soybean variety Select-302

\begin{tabular}{|c|c|c|c|c|c|c|c|c|c|c|c|}
\hline \multirow{3}{*}{ № } & \multirow{3}{*}{ Preparation } & \multicolumn{10}{|c|}{ Micro \& Macroelements $(\mathrm{Mg} / \mathrm{Kg})$} \\
\hline & & \multicolumn{2}{|c|}{ Copper } & \multicolumn{2}{|c|}{ Iron } & \multicolumn{2}{|c|}{ Potassium } & \multicolumn{2}{|c|}{ Calcium } & \multicolumn{2}{|c|}{ Sodium } \\
\hline & & Seed & Plant & Seed & Plant & Seed & Plant & Seed & Plant & Seed & Plant \\
\hline 1. & Control & 16.46 & 19.95 & 364.43 & 726.91 & 14052.12 & 12032.14 & 26089.63 & 39113.36 & 630.64 & 570.84 \\
\hline 2. & $\begin{array}{l}\text { UZHITAN } \\
\text { (Standard) }\end{array}$ & 9.60 & 26.14 & 98.72 & 982.74 & 11312.20 & 10087.38 & 3551.87 & 44351.62 & 495.81 & 389.11 \\
\hline 3. & $\begin{array}{l}\text { Ascorbate } \\
\text { chitosan }\end{array}$ & 4.17 & 15.26 & 79.73 & 182.34 & 635.37 & 13546.98 & 2243.16 & 26001.46 & 412.88 & 452.17 \\
\hline 4. & $\begin{array}{l}\text { Nanoascorbate } \\
\text { chitosan }(0.5 \%)\end{array}$ & 11.37 & 11.35 & 198.38 & 348.29 & 7508.49 & 6106.06 & 20971.30 & 19758.91 & 688.19 & 165.92 \\
\hline 5. & $\begin{array}{c}\text { Chitosan source } \\
(0.5 \%)\end{array}$ & 14.29 & 9.68 & 296.30 & 281.56 & 9146.84 & 6444.67 & 31241.52 & 19062.19 & 673.37 & 118.76 \\
\hline 6. & $\begin{array}{c}\text { Nanochitosan } \\
(0.5 \%)\end{array}$ & 24.80 & 7.29 & 192.83 & 127.16 & 12613.36 & 4298.78 & 25292.38 & 12545.19 & 307.65 & 65.69 \\
\hline 7. & $\mathrm{PMC} \mathrm{Cu}^{2+}: \mathrm{Ag} 7: 3$ & 12.59 & 10.02 & 317.01 & 100.97 & 10925.21 & 16536.68 & 30260.15 & 10165.21 & 949.69 & 137.68 \\
\hline 8. & $\mathrm{PMC} \mathrm{Cu}^{2+}: \mathrm{Ag} 8: 2$ & 9.85 & 10.03 & 111.75 & 124.19 & 13654.45 & 11568.13 & 23056.40 & 9366.15 & 626.97 & 77.56 \\
\hline 9. & $\begin{array}{l}\text { Uzgumi } \\
\text { (Standard) }\end{array}$ & 14.079 & 11.456 & 267.165 & 170.419 & 12440.083 & 14214.57 & 20631.00 & 13356.76 & 637.846 & 67.633 \\
\hline
\end{tabular}


Table 5 Determination of the micro- and macroelements contents in Selecta-302 soybean cultivar at the beginning of flowering and during fruiting stage

\begin{tabular}{|c|c|c|c|c|c|c|c|c|c|c|c|}
\hline \multirow[t]{3}{*}{ № } & \multirow{3}{*}{ Preparation } & \multicolumn{10}{|c|}{ Micro \& Macroelements $(\mathrm{Mg} / \mathrm{Kg})$} \\
\hline & & Copper & & Iron & & Potassium & & Calcium & & Sodium & \\
\hline & & Flowering & Fruiting & Flowering & Fruiting & Flowering & Fruiting & Flowering & Fruiting & Flowering & Fruiting \\
\hline 1. & $\begin{array}{l}\text { UZHITAN } \\
\text { (Standard) }\end{array}$ & 11.72 & 9382.7 & 189.35 & 196.1 & 11752.4 & 10186.3 & 16142.3 & 23246.7 & 894.4 & 637.34 \\
\hline 2. & $\begin{array}{l}\text { Gaucho } \\
\text { (Standard) }\end{array}$ & 10.37 & 9.46 & 301.56 & 214.52 & 11482.7 & 10177.7 & 16078.6 & 10934.3 & 807.5 & 232.7 \\
\hline 3. & $\begin{array}{l}\text { Ascorbate } \\
\text { chitosan }\end{array}$ & 5.23 & 9.38 & 287.19 & 176.32 & 12537.04 & 12113.32 & 21417.37 & 25318.7 & 641.63 & 308.38 \\
\hline 4. & $\begin{array}{l}\text { Nanoascorbate } \\
\text { chitosan } \\
(0.5 \%)\end{array}$ & 10.69 & 11.032 & 177.94 & 343.92 & 7704.72 & 6203.62 & 24179.40 & 20683.64 & 617.09 & 234.19 \\
\hline 5. & $\begin{array}{l}\text { Chitosan } \\
\text { source }(0.5 \%)\end{array}$ & 12.92 & 9.58 & 269.59 & 198.71 & 8264.72 & 5882.17 & 22141.21 & 16620.11 & 614.40 & 108.67 \\
\hline 6. & $\begin{array}{l}\text { Nanochitosan } \\
(0.5 \%)\end{array}$ & 16.71 & 8.27 & 187.32 & 172.50 & 9442.60 & 5117.87 & 23311.70 & 11455.73 & 278.81 & 117.54 \\
\hline 7. & $\begin{array}{l}\mathrm{PMC} \mathrm{Cu}^{2+}: \mathrm{Ag} \\
7: 3\end{array}$ & 11.49 & 9.21 & 301.01 & 127.31 & 9529.11 & 13126.8 & 25062.17 & 11651.12 & 862.92 & 273.81 \\
\hline 8. & $\begin{array}{l}\text { PMC } \\
\mathrm{Cu}^{2+}: \mathrm{Ag} 8: 2\end{array}$ & 10.32 & 9.16 & 121.46 & 125.30 & 11546.51 & 9693.19 & 2056.4 & 11661.58 & 546.46 & 107.45 \\
\hline
\end{tabular}

Table 6 Determination of the enzymes activity in seven-day-old seedlings of the Selecta-302 soybean variety treated with various nanopolymer preparations

\begin{tabular}{|c|c|c|c|c|c|c|c|}
\hline \multirow{2}{*}{$\begin{array}{l}\text { S. } \\
\text { № }\end{array}$} & \multirow{2}{*}{ Preparation } & \multirow{2}{*}{$\begin{array}{l}\text { Peroxidase } \\
(\mathrm{mg} / \mathrm{kg})\end{array}$} & \multirow{2}{*}{$\begin{array}{l}\text { Polyphenol oxidase } \\
\qquad(\mathrm{mg} / \mathrm{kg})\end{array}$} & \multirow{2}{*}{ Proteins } & \multicolumn{3}{|c|}{ Relative to control (\%) } \\
\hline & & & & & Peroxidase & Polyphenoloxidase & Proteins \\
\hline 1 & Control & 6.65 & 2.98 & 106.34 & - & - & - \\
\hline 2 & Uzgumi & 13.90 & 3.93 & 55.14 & 209.0 & 131.9 & 51.8 \\
\hline 3 & UZHITAN & 4.94 & 2.40 & 165.42 & 74.3 & 80.5 & 155.6 \\
\hline 4 & $\mathrm{PMC} \mathrm{Cu}^{2+}: \mathrm{Ag} 7: 3$ & 6.49 & 2.82 & 106.34 & 97.6 & 94.6 & 0 \\
\hline 5 & $\mathrm{PMC} \mathrm{Cu}^{2+}: \mathrm{Ag} 8: 2$ & 6.77 & 2.65 & 118.16 & 101.8 & 88.9 & 111.1 \\
\hline 6 & Chitosan source & 5.92 & 2.06 & 118.1 & 89.0 & 69.1 & 111.1 \\
\hline 7 & Nanochitosan & 7.89 & 3.42 & 86.65 & 118.6 & 112.8 & 81.5 \\
\hline 8 & Ascorbate chitosan & 11.85 & 2.26 & 157.54 & 178.2 & 75.8 & 148.1 \\
\hline 9 & $\begin{array}{c}\text { Nanoascorbate } \\
\text { chitosan }\end{array}$ & 8.46 & 3.62 & 70.89 & 127.2 & 121.5 & 66.7 \\
\hline
\end{tabular}

concentration, the highest iron content was observed during flowering in plants grown from seeds treated with Gaucho, and it was 1.60 times higher than the plants treated with the second standard UZHITAN. While the lowest iron concentration was observed during the period of fruit formation in plants grown from seeds treated with $\mathrm{PMC} \mathrm{Cu}^{2+}: \mathrm{Ag} \mathrm{8:2.}$

In terms of potassium concentration, seeds treated with ascorbate chitosan exceeded than those treated with the standard UZHITAN and Gaucho and this was 1.1-and 1.2 folds higher than the standard during flowering and fruit formation respectively. All the tested nano preparations except PMC Cu2+:Ag8:2 have higher calcium concentrations than the both tested standard during flowering. The greatest calcium content during flowering was observed in the

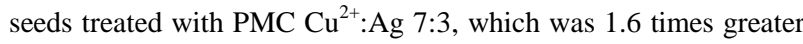
than that in seeds treated with the standard during fruit formation.
While at the fruiting stage, the highest calcium content was observed under Ascorbate chitosan treatment. The sodium content during flowering and fruit formation decreased in all samples as compared to the standard. Thus, the contents of micro-and macroelements in plants from seeds treated with nanopolymer preparations exhibited an uneven distribution in terms of concentration.

During the current study, enzymatic activities were also determined in the seven-day-old seedlings of soybean variety Selecta-302. The data in table 6 showed that the highest activity of the enzyme peroxidase occurred in soybean seeds treated with Uzgumi (13.90) and this was more than 2 times higher than that in the control. Further, seedlings treated with UZHITAN, chitosan, nanochitosan, $\mathrm{PMCCu}^{2+}: \mathrm{Ag} \quad 7: 3$, and $\mathrm{PMCCu}^{2+}: \mathrm{Ag}$ 8:2 also exhibited higher peroxidase activity than control seedlings. 
Similarly, the activity of polyphenol oxidase was also reported highest in seeds treated with Uzgumi (3.93) while it was lowest in seeds treated with chitosan (2.06, or 1.9 times lower).

Among the tested nano-preparations, the lowest protein activity was reported in seeds treated with standard Uzgumi (- 55.14), and this was almost 3 times lower than that in seeds treated with UZHITAN (- 165.42) and almost 2 times lower than that in seeds treated with ascorbate chitosan, chitosan, and $\mathrm{PMCCu}^{2+}: \mathrm{Ag}$ 8:2.

Soybean is susceptible to many fungal, bacterial, and viral diseases. Some most common soybean diseases and pathogens are charcoal rot (Macrophomina phaseolina), Fusarium wilt, Rhizoctonia, anthracnose, brown stem rot (Cadophora gregata), Phomopsis, stem rot (Sclerotonia), stem cancer (Diaporthe phaseolorum), soybean cyst nematodes, and Asian soybean rust (Phakopsora pachyrhizi). These diseases can cause significant crop losses. Under harsh conditions, soybean nematodes or Asian soybean rust could destroy the crop. In the current study, the incidence of Fusarium strain on soybean leaves and roots was estimated at the Maigir Yusufkhon farm (Figure 1). Similar types of results was reported by Brooker et al. (2007).

The results of the study showed that soybean treated with nanoascorbate chitosan, ascorbate chitosan, and $\mathrm{PMCCu}^{2+}: \mathrm{Ag} \mathrm{7:3}$ was less susceptible to disease. The most susceptible plants were those treated with Gaucho (standard), UZHITAN (standard), and

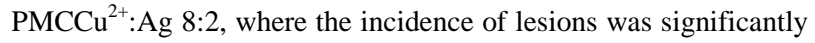
higher than the standard one.

At the same farm during the growing season of experimental crops, phenological and biometric observations of soybean plant development were carried out (Tables 7-8). The data in table 7 revealed that plants treated with the nano preparations were superior to those treated with the standards UZHITAN and Gaucho at all phases of development. Harvesting of plants from seeds treated with ascorbate chitosan, nanoascorbate chitosan, and nanochitosan was 5-6 days earlier than that of plants from seeds treated with the standard. Similar types of findings were reported by Egorov et al. (2008).

Biometric measurements and observations are presented in Table 8. Plants treated with the nanoascorbate chitosan, ascorbate chitosan, PMC $\mathrm{Cu}^{2+}: \mathrm{Ag} \quad 7: 3$, and $\mathrm{PMC} \mathrm{Cu}^{2+}: \mathrm{Ag} \quad 8: 2$ nanopolymer preparations were superior to those treated with other preparations. The weights of 1000-grain under these preparations were greater than those treated with the Gaucho standard by $17 \mathrm{~g}, 14.6 \mathrm{~g}, 13.5$ $\mathrm{g}$, and $11.9 \mathrm{~g}$, respectively. Productivity under the chitosan and PMC treatments was 4.5-6.1 c/ha and 3.3-5.1 c/ha higher than the control respectively.

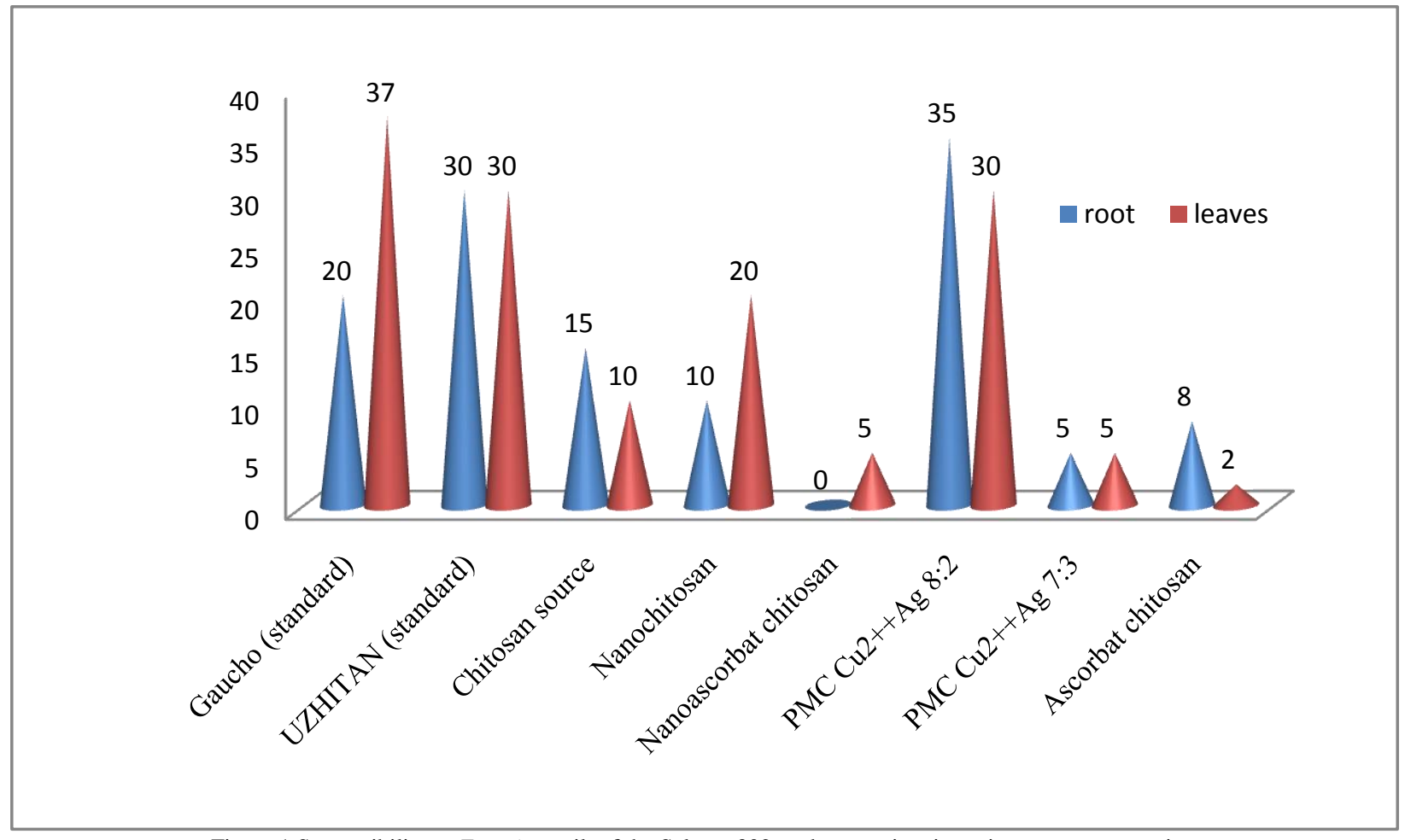

Figure 1 Susceptibility to Fusarium wilt of the Selecta-302 soybean variety in various nano-preparation

Journal of Experimental Biology and Agricultural Sciences http://www.jebas.org 
Table 7 Phenological observations of soybean variety Select-302 crops at Moygir Yusufkhon Farm

\begin{tabular}{|c|c|c|c|c|c|c|c|c|c|c|}
\hline$\stackrel{01}{2}$ & 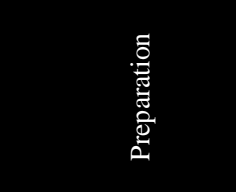 & 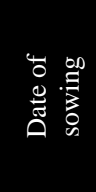 & 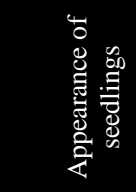 & 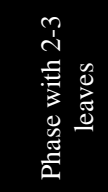 & 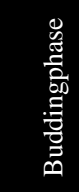 & 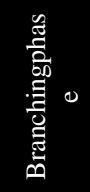 & 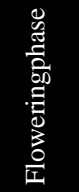 & 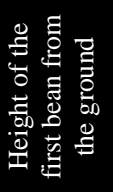 & 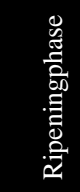 & $\begin{array}{l}\vec{y} \\
\stackrel{0}{0} \\
\text { 壳 }\end{array}$ \\
\hline 1 & Gaucho (standard) & 03.04 & 15.04 & 01.05 & 14.05 & 21.05 & 07.06 & 16.06 & 12.08 & 17.09 \\
\hline 2 & UZHITAN & 03.04 & 14.04 & 01.05 & 13.05 & 19.04 & 06.06 & 15.06 & 10.08 & 15.09 \\
\hline 3 & Ascorbate chitosan & 03.04 & 13.04 & 28.04 & 10.05 & 17.05 & 04.06 & 13.06 & 08.08 & 11.09 \\
\hline 4 & $\begin{array}{l}\text { Nanoascorbate } \\
\text { chitosan }\end{array}$ & 03.04 & 12.04 & 27.04 & 10.05 & 17.05 & 04.06 & 13.06 & 08.08 & 11.09 \\
\hline 5 & Chitosansource & 03.04 & 13.04 & 28.04 & 11.05 & 18.05 & 05.06 & 14.06 & 09.08 & 13.09 \\
\hline 6 & Nanochitosan & 03.04 & 13.04 & 28.04 & 10.05 & 17.05 & 04.06 & 13.06 & 08.08 & 12.09 \\
\hline 7 & $\mathrm{PMC} \mathrm{Cu}^{2}: \mathrm{Ag} 8: 2$ & 03.04 & 14.04 & 01.05 & 11.05 & 18.05 & 05.06 & 14.06 & 08.08 & 13.09 \\
\hline 8 & $\mathrm{PMC} \mathrm{Cu}^{2+}: \mathrm{Ag} 7: 3$ & 03.04 & 13.04 & 28.04 & 11.05 & 18.05 & 05.06 & 14.06 & 08.08 & 13.09 \\
\hline
\end{tabular}

Table 8 Biometric observations of the nano preparation application on the Selecta-302 soybean variety at Moygir Yusufkhon Farm

\begin{tabular}{|c|c|c|c|c|c|c|c|c|c|c|}
\hline № & Options & $\begin{array}{c}\text { Plant } \\
\text { height } \\
(\mathrm{cm})\end{array}$ & $\begin{array}{l}\text { Height of } \\
\text { the first } \\
\text { bean from } \\
\text { the ground } \\
(\mathrm{cm})\end{array}$ & $\begin{array}{l}\text { Number of } \\
\text { beans per } \\
\text { plant (pcs.) }\end{array}$ & $\begin{array}{c}\text { Number } \\
\text { of } \\
\text { grains } \\
\text { per pod } \\
\text { (pcs.) }\end{array}$ & $\begin{array}{l}\text { Grains / } \\
\text { plant and } \\
\text { their } \\
\text { mass }\end{array}$ & $\begin{array}{l}\text { Weight } \\
\text { of seeds } \\
\text { from one } \\
\text { plant }(\mathrm{g})\end{array}$ & $\begin{array}{l}\text { Weight } \\
\text { of } \\
1000 \\
\text { grains } \\
\text { (g) }\end{array}$ & $\begin{array}{c}\text { Number } \\
\text { of plants } \\
\text { per } \\
\text { thousand } \\
\text { hectares }\end{array}$ & $\begin{array}{l}\text { Productivity } \\
\text { (t/ha) }\end{array}$ \\
\hline 1 & Gaucho(standard) & 133.5 & 21.9 & 56.2 & 2.4 & 138.6 & 19.2 & 138.8 & 210 & 29.1 \\
\hline 2 & UZHITAN & 135.6 & 21.2 & 59.1 & 2.3 & 142.3 & 20.9 & 142.7 & 215 & 30.6 \\
\hline 3 & Chitosansource & 137.4 & 19.7 & 59.9 & 2.5 & 155.5 & 24.1 & 146.3 & 207 & 32.2 \\
\hline 4 & Nanochitosan & 136.6 & 19.4 & 60.3 & 2.7 & 157.3 & 25.2 & 152.0 & 204 & 32.1 \\
\hline 5 & $\begin{array}{l}\text { Ascorbate } \\
\text { chitosan }\end{array}$ & 136.8 & 19.4 & 60.8 & 2.7 & 160.2 & 25.4 & 153.4 & 210 & 33.6 \\
\hline 6 & $\begin{array}{l}\text { Nanoascorbate } \\
\text { chitosan }\end{array}$ & 144.5 & 19.6 & 62.8 & 2.8 & 174.4 & 27.8 & 155.8 & 202 & 35.2 \\
\hline 7 & $\begin{array}{l}\mathrm{PMC} \mathrm{Cu}^{2+}: \mathrm{Ag} \\
8: 2\end{array}$ & 143.3 & 19.8 & 62.2 & 2.7 & 168.3 & 26.7 & 150.7 & 193 & 32.4 \\
\hline 8 & $\begin{array}{l}\mathrm{PMC} \mathrm{Cu}^{2+}: \mathrm{Ag} \\
7: 3\end{array}$ & 143.5 & 19.9 & 62.3 & 2.8 & 169.9 & 27.1 & 152.3 & 201 & 34.2 \\
\hline
\end{tabular}

Thus, this research has shown that nanopolymer preparations not germination of soybean seeds. Further, the preparations, only have stimulatory and fungicidal properties but also have a nanoascorbate chitosan (4:1) @ 0.5\%, $\mathrm{PMCCu}^{2+}: \mathrm{Ag}^{7: 3,}$ and significant effect on the micro and microelements. The applied nano preparations had a stimulatory effect on development and can be recommended for use in encapsulating seeds after a few more studies under different environmental conditions. Similar types of results were reported by various researchers who evaluated the effect of various nano preparation on the soybean crop (Priester et al., 2012; Yoon et al., 2014; Chau et al., 2019; Coman et al. (2019).

\section{Conclusion}

Results of the study can be concluded that various nanopolymer preparations such as nanoascorbate chitosan (4:1)@ 0.5\% and nanochitosan (90 kDa) @0.5\% positively affect the laboratory

$\mathrm{PMCCu}^{2+}: \mathrm{Ag} 8: 2$ have higher biological activity than the control and standard. Similarly, various nano polymer preparations have left their effect on the content of micro and macro elements. Among these $\mathrm{PMCCu}^{2+}: \mathrm{Ag} \mathrm{8:2} \mathrm{encapsulation} \mathrm{had} \mathrm{almost} 1.5$ times higher concentrations than that in one-month-old plants

The use of nano preparation for the treatment of Selecta-302 soybean seeds favorably affects the contents of micro-and macroelements and contributes to a more uniform distribution of the concentration of these elements. In the case of enzymatic and protein concentration, various nano preparations showed superiority over the recommended standard preparation Uzgumi and UZHITAN, the lowest protein activity was found in seeds 
treated with Uzgumi (- 55.14), which was almost 3 times lower than that in seeds treated with UZHITAN (- 165.42) and almost 2 times lower than that in seeds treated with ascorbate chitosan,

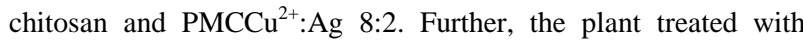
various nano preparations such as nanoascorbate chitosan, ascorbate chitosan, and $\mathrm{PMCCu}^{2+}: \mathrm{Ag} 7: 3$ were less susceptible to disease.

\section{Conflict Of Interest}

Authors would hereby like to declare that there is no conflict of interests that could possibly arise.

\section{References}

Aktuganov GE, Melentyev AI, Shirokov AV (2003) Colloidal chitosan as an affinity adsorbent for the purification of chitosanase strain Bacilus sp. 739. Biotechnology (6): 3-9.

Astafurova TP, Morgalev YUN, Zotikova AP, Verkhoturova GS, Mikhailova SI, Burenina AA, Zaitseva TA, Postovalova VM, Tsytsareva LK, Borovikova GV (2011) Effect of titanium dioxide and alumina nanoparticles on the morphophysiological parameters of plants. TomskStateUniversityJournalBiology 1 (13): 113-122.

Brooker NL, Lagnanalle CD, Zlatanic A, Javni I, Petrovic Z (2007) Soy polyol formulations as novel seed treatments for the management of soil-borne diseases of soybean. Communications in Agricultural and Applied Biological Sciences 72: 35-43. https://www.ncbi.nlm.nih.gov/pubmed/18399422.

Bykova VM, Ezhova EA, Nemtsov SV (2004) Some aspects of the use of chitin and chitosan as flocculants. Agrarian Russia 5: 30-31.

Chau NH, Doan QH, Chu TH, Nguyen TT, Trong HD, Ngo QB (2019) Effects of Different Nanoscale Microelement-Containing Formulations for Presowing Seed Treatment on Growth of Soybean Seedlings. Journal of Chemistry Volume, Article ID 8060316, 8 pageshttps://doi.org/10.1155/2019/8060316

Cheng P, Chen X, Liu Q, Sun L, Luo Y, Shi J (2017) Fate and transformation of $\mathrm{CuO}$ nanoparticles in the soil-rice system during the lifecycle of rice plants. Environmental Science \& Technology 51, 4907-4917.

Cheng W, Xu X, Wu F, Li J (2016) Synthesis of cavity-containing iron oxide nanoparticles by hydrothermal treatment of colloidal dispersion. Materials Letters 164: 210-212.

Chirkov SN (2002) Antiviral activity of chitosan. Applied Biochemistry and Microbiology 38 (1): 5-13.

Coman V, Oprea I, Leopold LF, Vodnar DC, Coman C (2019) Soybean Interaction with Engineered Nanomaterials: A Literature Review of Recent Data. Nanomaterials 9: 1248
Didenko LV, Gerasimenko DV, Konstantinova ND, Silkina TA, Avdienko ID, Bannikova GE, Varlamov VP (2005) Ultrastructural study of the effects of chitosan on Klebsiella and staphylococci. Bulletin of Experimental Biology and Medicine 140 (9): 343-347.

Egorov NP, Shafronov OD, Saratov DN, Egorov EV (2008) Development and conduct of an experimental assessment of the effectiveness of the use in plant growing of new types of fertilizers obtained using nanotechnology. Bulletin of the Nizhny Novgorod University. N.I. Lobachevsky. Chemistry 6: 94-99.

Fedorenko VF, Buklagin DS, Golubev IG (2006) Directions for the use of nanotechnology and nanomaterials in the agricultural sector and the tasks of information support for their development. M. Nanotechnology - production. Pp. 409-413.

Ge Y, Priester JH, Van De Werfhorst LC, Schimel JP, Holden PA (2013) Potential mechanisms and environmental controls of TiO 2 nanoparticle effects on soil bacterial communities. Environmental Science \& Technology 47 (24), 14411 - 14417.

Gerasimenko DV, Avdienko ID, Bannikova GE, Zueva OYu, Varlamov VP (2004) Antibacterial activity of water soluble low molecular weight chitosans in relation to various microorganisms. Applied Biochemistry and Microbiology 40 (3): 301-306.

Ghormade V, Deshpande MV, Paknikar KM (2011) Perspectives for nano-biotechnology enabled protection and nutrition of plants. Biotechnology Advances 29 (6): 792 - 803.

Hernandez-Viezcas JA, Castillo-Michel H, Andrews JC, Cotte M, Rico C, Peralta-Videa JR, Ge Y, Priester JH, Holden PA, GardeaTorresdey JL (2013) In situ synchrotron X-ray fluorescence mapping and speciation of $\mathrm{CeO} 2$ and $\mathrm{ZnO}$ nanoparticles in soil cultivated soybean (Glycine max). ACS Nano 7 (2): 1415 - 1423.

Ilyin LA, Andrianova IE, Glushkov VA, Bannikova GE, Varlamov VP (2004) Therapeutic and prophylactic properties of low molecular weight chitosan in experimental radiation injury. Radiation biology. Radioecology 44 (5): 547-549.

Johansen A, Pedersen AL, Jensen KA, Karlson U, Hansen BM, Scott-Fordsand JJ, Winding A (2008) Effects of C 60 fullerene nanoparticles on soil bacteria and protozoans. Environmental Toxicology and Chemistry 27 (9): $1895-1903$.

Kandrashina TF (2006) Influence of encapsulation of cotton seeds with polymer compositions on their germination. Abstract of diss. on sois. student step.kand. biol. sciences. Dushanbe,. P.135

Kulikov SN, Alimova FK, Zakharova NG, Nemtsev SV, Varlamov VP (2006a) Biological products with different mechanisms of 
action to combat potato fungal diseases. Applied Biochemistry and Microbiology 42 (1): 86-92.

Kulikov SN, Chirkov SN, Ilyina AV, Lopatin SA, Varlamov VP (2006b) The effect of the molecular weight of chitosan on its antiviral activity in plants. Applied Biochemistry and Microbiology 42 (2): 224-228.

Lin D, Xing B (2007) Phytotoxicity of nanoparticles: inhibition of seed germination and root growth. Environmental Pollution 150: 243-250.

López-Moreno ML, de la Rosa G, Hernández-Viezcas JA, Castillo-Michel H, Botez CE, Peralta-Videa JR, Gardea-Torresdey JL (2010) Evidence of the differential biotransformation and genotoxicity of $\mathrm{ZnO}$ and $\mathrm{CeO} 2$ nanoparticles on soybean (Glycine max) plants. Environmental Science \& Technology44, 7315-7320.

Milusheva RYu, Kodyakov AA, Ruban IN, Voropaeva NL, Rashidova SSh (2002) The effect of chitin and chitosan on the suppression of the pathogen Fuzarium oxysporium during encapsulation of rice seeds. Abstracts International scientific and practical Conference "Theoretical and practical foundations and prospects for the development of selection and seed production of cotton." Tashkent.Pp. 130-131.

Nowack B, Ranville JF, Diamond S, Gallego-Urrea JA, Metcalfe C, Rose J, Horne N, Koelmans AA, Klaine SJ (2012) Potential scenarios for nanomaterial release and subsequent alteration in the environment. Environmental Toxicology and Chemistry 31 (1): 50 - 59.

Pomogaylo AD, Rosenberg AS, Uflyand IE (2000) Metal nanoparticles in polymers. M Chemistry, Pp. 672.

Priester JH, Ge Y, Mielke RE, Horst AM, Moritz SC, Espinosa K, Gelb J, Walker SL, Nisbet RM, An YJ, Schimel JP, Palmer RG, Hernandez-Viezcas JA, Zhao L, Gardea-Torresdey JL, Holden PA (2012) Soybean susceptibility to manufactured nanomaterials with evidence for food quality and soil fertility interruption. Proceedings of the National Academy of Sciences of the United States of America109 (37): 14734-14735.

Priester JH. Ge Y, Chang V, Stoimenov PK, Schimel JP, Stucky GD, Holden PA (2013) Assessing interactions of hydrophilic nanoscale TiO 2 with soil water. Journal of Nanoparticle Research 15 (9): 1899 DOI: 10.1007/s11051-013-1899-4.

Rashidova DK, Shpilevsky VN, Rashidova SSh, et al. (2008) The effectiveness of the use of the polymer formulation of chemical plant protection products UZHITAN. AGROILM-Tashkent 3: 23.

Rashidova SS, Voropaeva L, Kozubaev SS, Rashidova DK (2005) Encapsulation is an environmentally friendly factor in stimulating cotton seeds. New Advances in Chemistry and Chemical Technology of Plant Raw materials, Book-2, Barnaul-. -p. 619-622

Rashidova SSh, Milusheva RYu (2009) Chitin and chitosan Bombyxmori. Synthesis, properties and application. T., Fan Publishing House.Pp. 246

Rashidova SSh, Oksengendler BL, Turaeva NN (2013) Synergetics of encapsulation of seeds of agricultural crops. MonographTashkent: Publishing house "FAN", Pp. 125.

Rashidova SSh, Voropaeva NL (2006) Water-soluble polymer blends, Tashkent, Fan, Pp.187

Rashidova SSh., Voropaeva NL, Milusheva RYu, Akhymbetova G, Akhmedova H, Nightingale DI, Ruban IN (2006) Silkworm chitosan is a promising source of crop growth regulators. VIII Int. Confer. "Modern. Prospects in the research. chitin and chitosan "(RosHit 2006) and the III Congress of Ross. Hit. Society. Kazan, June 13-17, p. 353-357.

RUz patent No. IAP 03956 Seed encapsulation method (2009) Rashidova S.Sh., Sarymsakov A.A., Ruban I.N., Rashidova D.K. and others. Official newsletter., No. 7.

Sendra M, Yeste MP, Gatica JM, Moreno-Garrido I, Blasco J (2017) Homoagglomeration and heteroagglomeration of TiO2, in nanoparticle and bulk form, onto freshwater and marine microalgae. Science of the Total Environment 592: 403-411.

Shah BR, Li Y, Jin W, An Y, He L, Li Z, Xu W, Li B (2016) Preparation and optimization of Pickering emulsion stabilized by chitosan-tripolyphosphate nanoparticles for curcumin encapsulation. Food Hydrocolloids 52: 369-377.

Stevanoic MM, Skapin SD, Bracko L, Milenkovic M, Petkovic J, Filipic M (2012) Poly (lactideco-glycolide)/silver nanoparticles: Synthesis, characterization, antimicrobial activity, cytotoxicity assessment and ROS-inducing potential. Polymer N53: 2818-2828.

Syrmolot OV (2015) Test results of biological preparations in the control of root rots. In: Collection o f scientific articles based on materials of the coordination meeting on soybean areas of the Far East and Siberia held at 09-10 September 2015. Available at http://vniisoi.ru/wp-content/uploads/2014/11/Collection-ofscientific-articles-on-materials-of-the-coordination-meetingssoybeans-09-10.09.2015.pdf access on 15th August 2020.

Tamuly C, Saikia I, Hazarika M, Das MR (2014) Reduction of aromatic nitro compounds catalyzed by Biogenic $\mathrm{CuO}$ nanoparticles. RSC Advances 4: 53229-53236.

Tikhonov VE, Stepnova EA, Babak VG, Yamskov IA, PalmaGuerrero J, Jansson HB, Lopes-Llorea LV, Salinas J, Gerasimenko 
DV, Avdienko ID, Varlamov VP (2000) Bactericidal and antifunga activities of low molecular weight chitosan and its N-2/(3)-(dodec-2enyl)succinoyl/-derivatives. Carbohudr Polymers 64 (1): 66-72.

Tong Z, Bischoff M, Nies L, Applegate B, Turco RF (2007) Impact of fullerene (C60) on a soil microbial community. Environmental Science \& Technology 41 (8): 2985 - 2991.

Varlamov VP, Bannikova GE, Andrianova IE. et al. (2005) Prerequisites for the creation and possibility of using low molecular weight chitosan as an anti-radiation agent. Scientific basis for the protection of animals from eco toxicants, radionuclides and pathogens of dangerous infectious diseases. Materials of the international symposium. G. Kazan. Part 1, p. 289-294.

Vasyukova NI, Zinovieva SV, Ilyinskaya LI, Transition EA, Chalenko GI, Gerasimova NG, Ilyina AV, Varlamov VP,
Ozeretskovskaya OL (2001) Modulation of disease resistance of plants using water-soluble chitosan. Applied Biochemistry and Microbiology 37 (1) : 115-122.

Yoon SJ, Kwak JIl, Lee WM, Holden PA, An YJ (2014) Zinc oxide nanoparticles delay soybean development: A standard soil microcosm study. Ecotoxicology and Environmental Safety 100: 131-137.

Zeng DF, Zhang L (2010) A novel environmentally friendly soybean seed-coating agent. Acta Agriculturae Scandinavica, Section B-Soil \& Plant Science 60 (6): 545-551,

Zorin EV (2004) Features of the effect of presowing treatment of potato tubers seeds with ultrafine powders and salts of iron and copper on their yield properties. M: Dis. Candidate of Agricultural Science- Pp. - 124. 